\title{
The Influence of Carbon Tax on the Feasibility of Industrial Project: A Gase Study of Heat Exchanger Replacement at PT Kaltim Methanol Industri, Indonesia
}

\author{
Wingo Wira Dewanatan ${ }^{1}$ \\ Muhammad Kurniawan Adiputra ${ }^{1}$ \\ Imam Karfendi Putro ${ }^{1}$ \\ Soni Hartanto ${ }^{1}$ \\ Jonas Kristanto ${ }^{2}$ \\ Muhammad Mufti Azis *,2 \\ ${ }^{1}$ PT Kaltim Methanol Industri, Bontang Plant Site, Komplek Pupuk Kaltim, Bontang Utara, \\ Kota Bontang, East Kalimantan, Indonesia 75321 \\ ${ }^{2}$ Department of Chemical Engineering, Faculty of Engineering, Universitas Gadjah Mada, Jl. \\ Grafika No. 2, Kampus UGM, Special Region of Yogyakarta, Indonesia 55281 \\ "e-mail: muhammad.azis@ugm.ac.id
}

Petrochemical industries have faced growing pressure to decrease their carbon emission from direct and indirect sources. This work aims to demonstrate a carbon tax's introduction to a feasibility study on the heat exchanger (HE) replacement project at PT Kaltim Methanol Industri, Indonesia. The project was aimed to avoid methanol release as much as $48.88 \mathrm{MT}$ /year. The release of methanol can also be associated with $\mathrm{CO}_{2}$ emission with an emission factor of 0.6 ton $\mathrm{CO}_{2} \mathrm{e} /$ ton methanol. Here, we investigated the influence of inclusion and exclusion of carbon tax to monetize the $\mathrm{CO}_{2}$ release. From the project investment point of view, carbon tax inclusion is expected to increase the cost-saving. Introduction of the carbon tax as high as $10 \mathrm{USD} /$ ton $\mathrm{CO}_{2} \mathrm{e}$ with $5 \%$ annual increase gives IRR value of $7.06 \%$ with Payout Time (PoT) of ca. 11 years. The IRR value without carbon tax scenario is $6.68 \%$ with the same range of PoT. Hence, the inclusion of carbon tax may increase the feasibility of the project. This work has demonstrated the positive role of the carbon tax to increase the feasibility of a project which inlines with the national initiatives to curb the $\mathrm{CO}_{2}$ emission from chemical industries. It is also worth noting that introduction of carbon tax should be accompanied by a reorganization of government incentives, including several financial policies to create a conducive atmosphere for investors in Indonesia.

Keywords: Carbon Tax, Heat Exchanger Replacement, Indonesia, IRR, Methanol, PoT

\section{INTRODUCTION}

Petrochemical industries play an important role in our modern life as they are responsible for producing a huge range of chemical products. There has been growing pressure for the petrochemical sector to be more sustainable by encouraging a shift to biobased raw materials, introducing carbon capture and 
storage (CCS), and gradually decarbonize the production process, including the heat and electricity generation (IEAGHG, 2019). Improving energy efficiency is paramount for chemical industries as energy consumption is often viewed as one of the highest costs and the largest contributor to emission.

Ensuring high performance of heat transfer equipment is one of the key elements to improve the energy efficiency in petrochemical production. Heat transfer equipment such as Heat Exchanger (HE) and furnace are common equipment found in all production stages. An LCA study of HE by Adolfson and Rashid (2016) revealed that the largest contributor to the Global Warming Potential (GWP) of HE is mainly during the HE's use phase. Thus, minimizing the environmental impact of $\mathrm{HE}$ operation is also an important goal for the industry.

A heat exchanger (HE) is a part of a large heat transfer network in a chemical plant that plays a vital role in facilitating energy transfer from hot streams to cold streams. A common problem found in $\mathrm{HE}$ is fouling and scaling, where undesired materials are accumulated inside HE. Due to fouling, the performance of $\mathrm{HE}$ decreases along with time. As a result, regular maintenance such as backwash and cleaning are often taken periodically to maintain the performance (Huda et al. 2020). HE fouling problems may possess a high cost for industries, and it is predicted that $\mathrm{HE}$ fouling gives additional costs as large as $0.25 \%$ of industrial countries' GDP (Müller-Steinhagen et al. 2011). In addition, $\mathrm{HE}$ fouling also responsible for $2.5 \%$ of the total anthropogenic emission of $\mathrm{CO}_{2}$
(Müller-Steinhagen et al. 2011).

There has been raising awareness to correlate the HE fouling not only to the economic impact but also to weigh in the environmental impact (Müller-Steinhagen et al. 2009). Jin et al. (2014) proposed a mathematical model to consider $\mathrm{HE}$ network performance by minimizing the economic and environmental impacts. Here, multi-objective optimization was performed by normalizing the economic and environmental factors to evaluate the HE networks' performance. Similarly, Kang et al. (2015) has developed multi-objective modeling of $\mathrm{HE}$ network by partitioning minimum approach temperature to minimize the annual cost and accumulation of $\mathrm{CO}_{2}$. Continuous monitoring and cleaning of $\mathrm{HE}$ due to fouling also require maintenance costs (Huda et al., 2020). However, up to a certain decline of performance, a decision-making analysis is needed to keep or replace the existing $\mathrm{HE}$.

Currently, the Indonesian government has committed to decrease greenhouse gas emissions by $26 \%$ from the BAU (business as usual) scenario by 2020 (Ratnawati 2016). Hence, introducing of the carbon tax has been an attractive tool to curb carbon emission in Indonesia (Ratnawati 2016, Ayu 2018). The price of the carbon tax as much as $\mathrm{Rp} 80,000 /$ ton $\mathrm{CO}_{2} \mathrm{e}$ with an annual increase of $5 \%$ has been proposed as a starting point in Indonesia (Ratnawati 2016). However, the introduction of the carbon tax have an adverse impact as it may slow down the GDP growth, decrease social welfare, and reduce industrial products' competitiveness (Ayu 2018). Hence, this policy should be balanced with other incentives for industries. A study by 
198 The Influence of Carbon Tax on the Feasibility of Industrial Project: A Case Study of Heat Exchanger Replacement at PT Kaltim Methanol Industri, Indonesia

Rokhmawati et al. (2015) pointed out that promoting environmental and social projects does not necessarily harm the financial performance of a company. Instead, it has a positive impact on the financial performance of a company as an addition in expense may encourage the board to increase the production efficiency and simultaneously reduce the environmental impact of the industry.

Moreover, this has been the spirit of the company's environmental performance rating program (PROPER program) in Indonesia. However, the study of carbon tax influence on Indonesia's industrial project is still limited in the current literature. Thereby, it is important to conduct a study to investigate the influence of carbon tax on the feasibility of a real industrial project in Indonesia.

The feasibility of an industrial project is often evaluated using IRR and PoT. A number of literature has demonstrated the use of both parameters for evaluation of industrial projects such as technoeconomic feasibility study on flare gas utilization (Dahlan et al. 2020), a prefeasibility study on wellhead generating unit (Muharam et al. 2018), or natural gas conversion process (Gradassi et al. 1995).

The present work's objective is to investigate the influence of carbon tax of a real industrial project of industrial $\mathrm{HE}$ replacement. Here, we use both internal rate of return (IRR) and payout time (PoT) as the decision-making tool for $\mathrm{HE}$ replacement. In this study, the cost associated with $\mathrm{HE}$ maintenance cost and the environmental cost will be considered. Hence, a better understanding of $\mathrm{HE}$ replacement decision making can be made.

\section{METHODOLOGY}

\section{Data extraction from KMI methanol plant}

The present study is conducted using industrial data from a 2019 annual mass and heat balance report of the methanol plant of PT Kaltim Methanol Industri (KMI) situated in Bontang, East Kalimantan, Indonesia. The plant has an annual capacity of 660000 MTPA of AA grade methanol with $99.85 \%$ purity (Putro et al. 2018).

This plant uses natural gas as raw material, which is purchased from a local source in East Kalimantan. The plant consists of chemical processes, namely reforming, synthesis, and purification unit. A final product in the form of liquid methanol is produced and sold abroad or domestically.

In one part of the plant called the methanol purification unit, pure methanol that leaves the distillation unit needs to be cooled below the standard boiling point (ca. $65^{\circ} \mathrm{C}$ ). For this purpose, a pure methanol stream is cooled from $120^{\circ} \mathrm{C}$ to ca. $40^{\circ} \mathrm{C}$ with a shell and tube HE denoted as 030-E09 unit. After leaving the 030-E09 unit, the methanol stream should be mixed with acold methanol stream from the third distillation column's reflux vessel to reach the targeted storage temperature of $38^{\circ} \mathrm{C}$.

\section{Estimation of methanol release}

The vapor pressure of pure methanol can be approximated using the Antoine equation, as shown by equation (1).

$$
P^{S}(\mathrm{mmHg})=10^{7.9701-\frac{1582.27}{239.7+T\left({ }^{\circ} \mathrm{C}\right)}}
$$


Next, the amount of methanol release (ton/year) was estimated using the ideal gas law, as shown by equation (2).

$$
\dot{m}=\frac{P^{s} \cdot V \cdot M W}{R \cdot T}
$$

The source of the methanol leak is located at the intermediate tank. The intermediate tank volume is $1109 \mathrm{~m}^{3}$ with a maximum capacity of $90 \%$ of total volume. Calculation of methanol release was made based on the following assumption:

- The initial tank level is $10 \%$ of total capacity

- The liquid methanol occupies from $10 \%$ to $90 \%$ of tank volume.

- The venting of gas only occurs due to the liquid filling activities in the tank that occurs 3 times a day.

- The initial pressure in the tank is already equal to the pressure of the venting valve.

- Ideal gas law applies.

\section{Calculation of Internal Rate of Return (IRR) and Pay Out Time (PoT)}

In order to evaluate the feasibility of this project, two parameters, namely the Internal Rate of Return (IRR) and Payout Time (PoT), were used. By using IRR, the rate of return of a certain investment could be determined. In addition, PoT shows the duration to recoup the initial investment and become profitable. The value of IRR and PoT were calculated by equation (3) and (4).

$$
\begin{gathered}
I=\sum_{j=1}^{N} \frac{C_{j}}{(1+I R R)^{j}} \\
P o T=\frac{I}{C}
\end{gathered}
$$

In equation (3) as well as (4), initial investment $(I)$ comprises the total investment made at the beginning (equipment cost and installation). At the same time, net cash flow $(C)$ consists of saving made each year after the initial investment. The saving value is determined by subtracting the cashflow after and before the HE replacement.

\section{RESULTS AND DISCUSSION}

\section{Evaluation of storage temperature}

Due to fouling in the 030-E09 unit for several years, the storage temperature of pure methanol has increased, which increases the methanol loss by evaporation and shows a few indications of methanol leak from the intermediate tank. It has also been found that several factors resulted in lower performance of the 030-E09 unit:

- Continuous defect in the installation of longitudinal baffle seal, which was found from annual inspection of the 030-E09 unit. As a result, there is a bypass of methanol flow and lower the heat transfer efficiency.

- The number of active tubes in the 030E09 unit had been decreased. Few tubes had been plugged and regularly replaced due to corrosion and erosion.

- The seawater source was taken from the lower point of seawater piping, which often contains solid deposits of ocean creatures or debris. Consequently, the cold fluid is more susceptible to causes fouling or plugging.

Figure 1 shows the recorded outlet temperature of the 030-E09 unit (blue), the 
200 The Influence of Carbon Tax on the Feasibility of Industrial Project: A Case Study of Heat Exchanger Replacement at PT Kaltim Methanol Industri, Indonesia

outlet temperature of the reflux drum from a distillation column (red), and the mixed temperature from the outlet of 030-E09 and reflux drum (green). As seen here, the outlet temperature of 030-E09 (030-TI016) is varied between $41-45^{\circ} \mathrm{C}$. The outlet temperature of the reflux drum (030-TI026) varied between $37-41^{\circ} \mathrm{C}$. As a result, the mixing temperature or denoted as storage temperature varied within the range of $40-$ $41^{\circ} \mathrm{C}$. As mentioned earlier, higher storage temperature can cause methanol release via evaporation. The higher storage temperature was mainly due to the inefficacy of 030-E09 unit to decrease the methanol temperature to the targeted temperature of $38^{\circ} \mathrm{C}$.

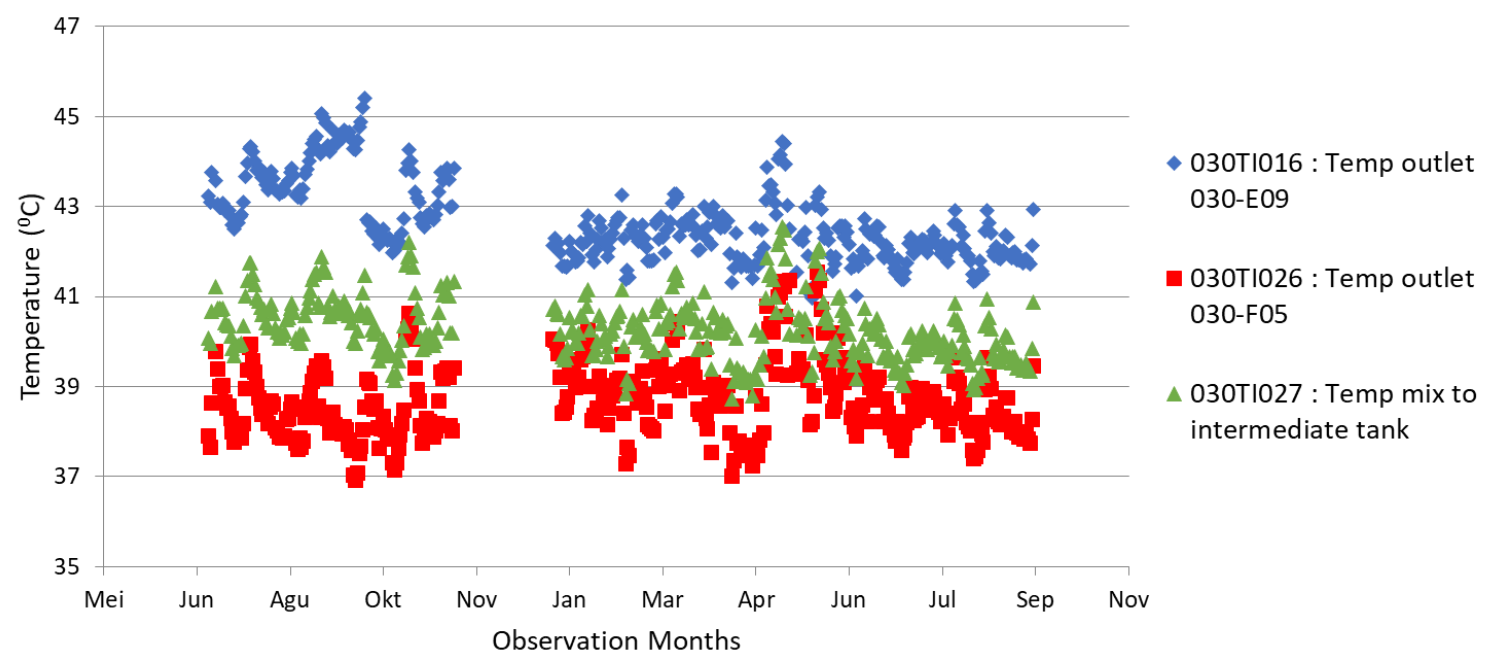

Fig. 1: Recorded temperature from the outlet of 030-E09 unit (blue), methanol stream from reflux drum of distillation unit (red), and the mixed temperature (red+blue=green).

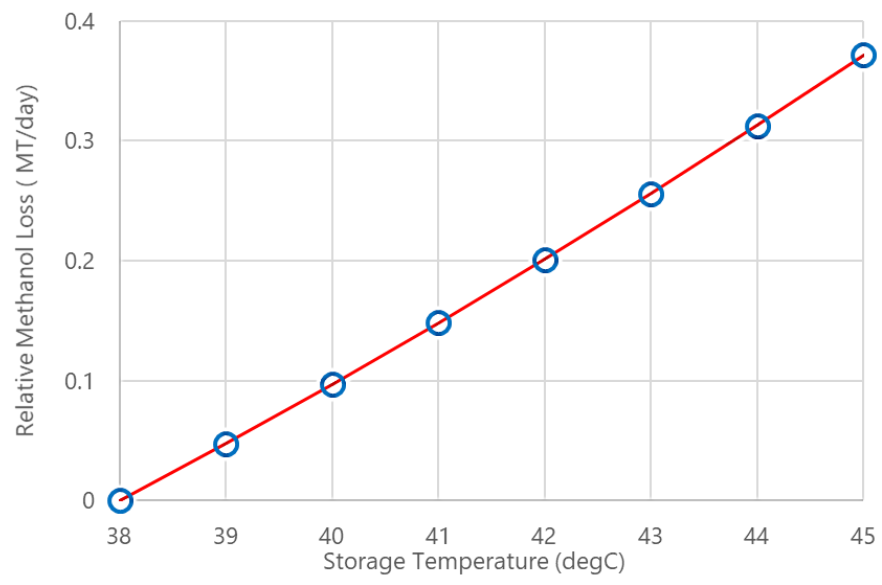

Fig. 2: The correlation between relative methanol loss and storage temperature. The baseline temperature for the calculation is $38^{\circ} \mathrm{C}$ 
The rate of methanol release at baseline or intended temperature of $38^{\circ} \mathrm{C}$ is $1.061 \mathrm{MT} /$ day. The estimation of methanol release at $41^{\circ} \mathrm{C}$ is $1.210 \mathrm{MT} /$ day, which gives the increase rate of $0.148 \mathrm{MT} /$ day compared to the baseline. Figure 2 shows the relative rate of methanol release compared to the intended temperature. For the economic evaluation, we have used a storage temperature of $41^{\circ} \mathrm{C}$. It will increase annual methanol release as high as 48.88 MT/year compared to baseline.

\section{Economic analysis}

The annual cash flow component of HE operational cost consists of a maintenance fee for cleaning, methanol loss, and carbon tax due to methanol release. Maintenance cost is needed for the cleaning of HE. The total cost of HE cleaning capped at 126 USD per cleaning. For methanol release, the price of methanol is assumed to be 250 USD/ton.

The release of methanol is also penalized with carbon tax at the basic rate of $10 \mathrm{USD} / \mathrm{ton}$ of $\mathrm{CO}_{2} \mathrm{e}$ with an annual increase of $5 \%$ (Ratnawati 2016). The emission factor of methanol from natural gas was taken from global methanol producer METHANEX at 0.6 ton $\mathrm{CO}_{2} \mathrm{e} /$ ton methanol (Methanex 2015). Lastly, the operating service of $\mathrm{HE}$ is estimated to be 20 years.

The new Shell and Tube HE unit price is 150,000 USD, and the installation cost is 1,900 USD. The new HE will maintain the average storage temperature to $38^{\circ} \mathrm{C}$. As a result, the annual methanol release was decreased from 399.15 to $350.28 \mathrm{MT} /$ year. Furthermore, the new HE has better fouling resistance, which resulted in the reduction of annual backwash cleaning frequency from 12 to 0.

Thus, the annual cash flow of HE replacement consists of net annual savings from the avoided methanol release and cleaning cost, initial investment, and salvage value in the $20^{\text {th }}$ year. The salvage value is assumed as $10 \%$ of its initial value. It is also assumed that cash flow is constant and not affected by any other external or unexpected events. As a result, the annual net cash flow can be computed, as illustrated in Figure 3. In addition, the plant operates 330 days per year, which gives an annual methanol saving of $48.88 \mathrm{MT} /$ year.

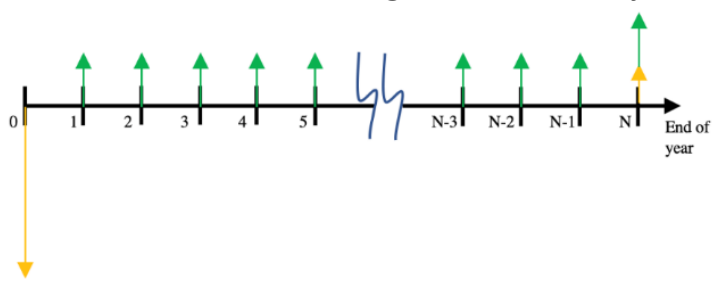

Fig. 3. The net cashflow of HE replacement project

\section{Calculation of IRR and PoT}

The feasibility of the HE replacement is evaluated by calculating the IRR and PoT values from $\mathrm{HE}$ replacement project. For this scenario, we have also estimated the net cash flow with and without a carbon tax (Table 1).

The IRR of the HE replacement project is $6.68 \%$ without the addition of carbon tax. Whereas the inclusion of carbon tax would cause an increase saving and thus increase the IRR to $7.06 \%$. The IRR values here are still higher than the current Bank Indonesia 7-day (reverse) repo rate of $4 \%$ (Bank Indonesia. 2020). The PoT of this program is 11.16 years without a carbon tax and 10.93 with the addition of carbon tax. The 
202 The Influence of Carbon Tax on the Feasibility of Industrial Project: A Case Study of Heat Exchanger Replacement at PT Kaltim Methanol Industri, Indonesia

PoT values here are higher than the values reported in (Adolfson and Rashid. 2016), ranging from 2.5-6.2 years. The lower values of PoT in (Adolfson and Rashid. 2016) are probably due to larger costsaving and inclusion of all costs, which is associated with the life cycle and operating cost of HE.

Table 1. The economic evaluation of HE replacement project

\begin{tabular}{lll}
\hline \multicolumn{1}{c}{ Parameters } & \multicolumn{1}{c}{ Description } \\
\hline $\begin{array}{l}\text { Carbon tax } \\
\text { (USD) }\end{array}$ & \multicolumn{1}{c}{$\begin{array}{c}10 \text { USD and } \\
\text { annual } \\
\text { increase of } \\
5 \%\end{array}$} \\
& \multicolumn{2}{c}{40 Metric Tons } \\
\hline $\begin{array}{l}\text { Annual } \\
\text { methanol } \\
\text { saving }\end{array}$ & $7.06 \%$ \\
\hline $\begin{array}{l}\text { Internal Rate } \\
\text { of Return (IRR) }\end{array}$ & $6.68 \%$ \\
\hline $\begin{array}{l}\text { Pay out Time } \\
\text { (PoT) }\end{array}$ & 11.16 years & 10.93 years \\
\hline
\end{tabular}

This work also demonstrates the influence of carbon tax on the feasibility of $\mathrm{HE}$ replacement with a small chemical release case. From the project investment point of view, the inclusion of carbon tax has been positive as it gives a marginal increase of IRR from 6.68 to $7.06 \%$.

The introduction of the carbon tax will force industries to minimize their operating cost by minimizing their emission. Consequently, industries will try to find a new way to decrease their expenditures by increasing process efficiency, which resulted in lesser $\mathrm{CO}_{2}$ emissions.

However, the introduction of a carbon tax should also be supported with numerous attractive incentives such as tax holidays, gas price discounts, or other schemes, which may stimulate the chemical industry to invest more in the environmental sector to reach a sustainable chemical company (Rokhmawati et al. 2015). Reorganization of government incentive scheme is important to minimize the carbon tax's adverse impact on GDP, as already pointed out by (Ayu 2018). It is also well known that large investments in developing countries face more risks than in developed countries. Bhattacharyya (2019) reported that investment in developing countries could be 6 to 9 times more expensive. De-risking measures are needed, such as policy de-risking and financial de-risking to create a conducive atmosphere for investors (Bhattacharyya, 2019).

\section{CONCLUSIONS}

An economic analysis of $\mathrm{HE}$ replacement has been investigated from a real industrial data of PT Kaltim Methanol Industri, Indonesia. The HE replacement is considered a cost-effective option to avoid methanol release of as much as 48.88 MT/year. The result shows that $\mathrm{HE}$ replacement is an attractive option as it gives an IRR value of $6-7 \%$, which is still higher than the current Bank Indonesia rate of $4 \%$.

This study also demonstrates the influence of carbon tax on the feasibility of $\mathrm{HE}$ replacement. By introducing an emission factor of $0.6 \mathrm{CO}_{2} \mathrm{e} /$ ton methanol and carbon tax of $10 \mathrm{USD} /$ ton of $\mathrm{CO}_{2} \mathrm{e}$ with an annual increase of $5 \%$, this study found that introduction of the carbon tax has a positive impact on the feasibility of $\mathrm{HE}$ replacement with a marginal increase of 
IRR from 6.68 to $7.06 \%$. The PoT with inclusion and exclusion of carbon tax is nearly the same at ca. 11 years.

With appropriate policies to decarbonize the petrochemical sector, introducing a carbon tax can be an attractive option for the government to curb $\mathrm{CO}_{2}$ emissions. However, the reorganization of government incentives, which includes a number of financial policies, is needed to create a conducive atmosphere for investors in Indonesia.

\section{ACKNOWLEDGEMENT}

This work has been financially supported by the contract between PT KMI and UGM with contract number: 025/SPKKMI/LOG/VIII/2020.

\section{NOMENCLATURE}

$$
\begin{array}{cl}
I R R & : \text { Internal Rate of Return } \\
P O T & : \text { Payout Time } \\
C & : \text { Net cashflow } \\
I & : \text { Initial investment } \\
T & : \text { Temperature }(\mathrm{K}) \\
V & : \text { Volume } \\
M W & : \text { Molecular weight } \\
R & : \text { Ideal gas constant } \\
\dot{m} & : \text { Mass flow rate }
\end{array}
$$

\section{REFERENCES}

1. Adolfson, M. and Rashid, S. (2016). "Life Cycle Assessment and Life Cycle Cost of Heat Exchanger", Chalmers University of Technology, Gothenburg, Sweden.

2. Ayu, P. (2018)."The Impact of Carbon Tax Application on the Economy and
Environment of Indonesia," Eur. J. Econ. Bus. Stud., 4(1), 110-120.

3. Bank Indonesia, www.bi.go.id, (2020). https://www.bi.go.id/en/moneter/bi7day-RR/data/Contents/Default.aspx (accessed September 2, 2020).

4. Bhattacharyya, S.C. (2019), "Energy Investment Issues BT - Energy Economics: Concepts, Issues, Markets and Governance", in: S.C. Bhattacharyya (Ed.), Springer London, London, pp. 469-491

5. Dahlan M. A., Pratama H. B., and Saptadji N. M. (2020) "Pre-feasibility Study of Condensing Wellhead Generating Unit Utilization in Partially Vapor Dominated System," IOP Conf. Ser. Earth Environ. Sci., 417

6. Gradassi M. J. and Green N. W. (1995) "Economics of natural gas conversion processes," Fuel Process. Technol., 42, 65-83

7. Huda, H., Handogo, R., Biyanto, T.R. Wu, W., Adi, V.S.K. (2020). "Oil Refinery Heat Exchanger Network Cleaning Scheduling Strategy with Unit Cleanability Consideration", ASEAN J. Chem. Eng., 20, 31-48.

8. IEAGHG, Sustainability in Petrochemicals, 2019.

9. Jin, Z.-L., Chen, X.-T., Wang, Y.-Q., Liu, M.-S. (2014). "Heat exchanger network synthesis based on environmental impact minimization", Clean Technol. Environ. Policy. 16, 183-187.

10. Kang, L., Liu, Y., Liang, X. (2015). "Multiobjective optimization of heat exchanger networks based on analysis of minimum temperature difference and accumulated $\mathrm{CO}_{2}$ emissions", Appl. Therm. Eng., 87, 736-748. 
204 The Influence of Carbon Tax on the Feasibility of Industrial Project: A Case Study of Heat Exchanger Replacement at PT Kaltim Methanol Industri, Indonesia

11. Methanex, Responsible Care and Sustainability Report, 2019. www.methanex.com.

12. Muharam Y., Giffari F., and Mahendra M. (2018) "Techno-economic feasibility of flare gas utilization using adsorbed natural gas," IOP Conf. Ser. Earth Environ. Sci., 105

13. Müller-Steinhagen, H., Malayeri, M.R. Watkinson, A.P. (2011). "Heat Exchanger Fouling: Mitigation and Cleaning Strategies," Heat Transf. Eng., 32, 189-196.

14. Müller-Steinhagen, H., Malayeri, M.R. Watkinson, A.P. (2009). "Heat Exchanger Fouling: Environmental Impacts", Heat Transf. Eng., 30, 773776.

15. Putro, I.K., Nugroho, A., Hasanudin, N. (2009). "Pemurnian Metanol dari Kandungan Tri Methyl Amine di PT. Kaltim Methanol Industri - Bontang Kaltim", J. Rekayasa Proses. 3, 30-36.

16. Ratnawati, D. (2016). "Carbon Tax Sebagai Alternatif Kebijakan Mengatasi Eksternalitas Negatif Emisi Karbon di Indonesia", Indones. Treas. Rev. J. Perbendaharaan, Keuang. Negara, Dan Kebijak. Publik., 1, 53-67.

17. Rokhmawati, A., Sathye, M., Sathye, S. (2015), "The Effect of GHG Emission, Environmental Performance, and Social Performance on Financial Performance of Listed Manufacturing Firms in Indonesia", Procedia - Soc. Behav. Sci., 211, 461-470. 